\title{
THE NORMAL ANTIDIURETIC MECHANISM IN MAN AND DOG; ITS REGULATION BY EXTRACELLULAR FLUID TONICITY ${ }^{1,2}$
}

\author{
By ALEXANDER LEAF 3 AND AUDLEY R. MAMBY \\ (From the Departments of Medicine of Harvard Medical School and the Massachusetts General \\ Hospital, Boston, Mass.)
}

(Submitted for publication August 9, 1951; accepted October 15, 1951)

The work of Verney $(1,2)$ has clearly demonstrated that the antidiuretic mechanism of the posterior pituitary is sensitive to changes in total effective solute concentration of the extracellular fluid. He postulates osmoreceptors which cause out-pouring of antidiuretic hormone of the posterior pituitary in response to an increased concentration of solute in the serum and inhibition of antidiuretic hormone production with dilution of the extracellular fluids.

Others have demonstrated antidiuretic activity in the urine or serum of rats $(3,4)$, cats $(5)$ and dogs $(6-8)$ following dehydration or after infusions of hypertonic saline solutions. Following water administration or hypophysectomy no antidiuretic activity is present in urine or serum.

The purpose of this paper is to further describe the mechanism in normal man and dogs which acts to preserve the total solute concentration of the serum within narrow limits, and to present the methods and form of presentation which will be used in an accompanying paper (9).

\section{METHODS AND PROCEDURE}

The data were obtained from ten separate studies on two normal male human adults and from 12 studies on three normal unanesthetized trained female dogs. Urine and serum collections were made before and at hourly intervals following administration of 670 to $3,000 \mathrm{ml}$. of water to the human subjects and 300 to $400 \mathrm{ml}$. of water by stomach tube to the dogs. Urine collections from the dogs were made by catheterization.

Serum sodium determinations were done in duplicate by the method of Butler and Tuthill (10). Serum and urine total solute concentrations were determined by the freezing point method utilizing an electrical resistance

\footnotetext{
1 Supported in part by a Grant-in-Aid from the American Heart Association.

2 Presented in part at the Forty-third Annual Meeting of the American Society for Clinical Investigation, Atlantic City, N. J., April 30, 1951.

3 National Research Council Fellow in the Medical Sciences, 1949-1951.
}

thermometer apparatus described by Crawford and $\mathrm{Ni}$ cosia (11). The apparatus was standardized with sodium chloride solutions of known concentration. The assumption was made, for convenience of expression, that the sodium chloride was totally dissociated and the results were expressed as milliosmols per liter. More correctly, total solute concentration should be expressed as the concentration in millimols of sodium chloride which produces a depression of the freezing point equal to that produced by the test material. This expression is simply obtained by dividing the reported concentration in milliosmols by two. All sera were measured without dilution while urines were diluted, if necessary, into the range of 100$300 \mathrm{mOsm} / \mathrm{L}$. This dilution, by changing the activity coefficient of certain solutes, introduces a slight but systematic error which does not affect our interpretations.

The serum assay for antidiuretic activity utilized four posthypophysectomized rats, ${ }^{4}$ individually weighing approximately 200 gms., in each determination. The animals were given $8 \mathrm{ml}$. of water per 100 square centimeters of surface area $(11.23 \times$ weight $\%$ by stomach tube following 12 hours fasting. Two-fifths of the water was administered initially and one-fifth at hourly intervals thereafter. Saline or serum inactivated by 48 hours storage was injected intraperitoneally at the start of the third hour of hydration. One to $2 \mathrm{ml}$. of fresh test serum, within 30 minutes of venipuncture, were injected intraperitoneally into each rat at the start of the fourth hour. The rats were kept in metabolism cages over funnels and all urine was collected during the third and fourth hours. Total solute concentration of the urines was then determined and the mean increase in concentration of the rats' urine during the hour following injection of the test material as compared with the preceding control hour was taken as the antidiuretic index. ${ }^{5}$

As seen in Table I, when only saline was injected there was no essential change in urine concentration during the third and fourth hours of the test-Part A. Similar results were obtained when serum from a hydrated subject replaced the second saline injection-Part B. However, when serum obtained from a dehydrated subject replaced the second injection an increase in urine concentration occurred-Part C. Part D shows what was

\footnotetext{
4 We are indebted to Dr. Charles Read for generously supplying us with operated rats.

5 The idea of using change in urine concentration as the index of antidiuretic activity was suggested by $\mathrm{Dr}$. J. D. Crawford who had utilized it prior to us.
} 
TABLE I

Examples of assays for antidiuretic actioity in serum

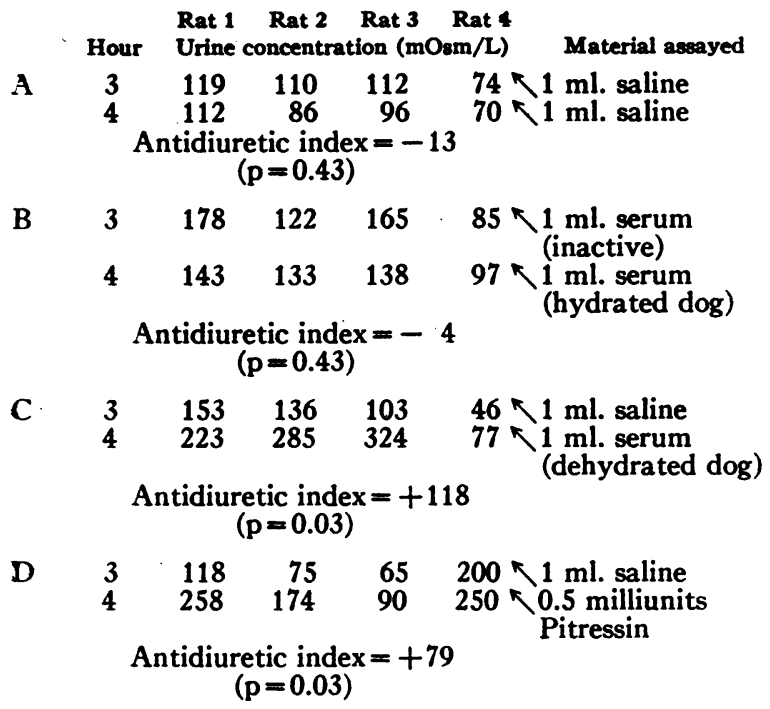

observed when 0.5 milliunit of Pitressin was substituted for the second saline injection.

The assays were treated statistically as follows. There were 30 control assays done in which no antidiuretic material was injected, giving a total of 115 observations of the response of individual rats. The mean change in urine solute concentration per rat was $+3.1 \mathrm{mOsm} / \mathrm{L}$ with a standard deviation of 47 . In these 30 control assays the mean number of rats per assay showing a change in urine concentration greater than one standard deviation above the mean of the control series was 0.83 with a standard deviation of 0.87 . Each test assay was then assessed to see whether the number of rats showing an increase of urine concentration greater than one standard deviation above the mean of the control series was significant. The value of " $p$ " following each antidiuretic index gives the probability of its significance. Values of " $p$ " of 0.03 or less were considered satisfactory confidence limits for this study.

No attempt was made to assign quantitative significance to the assay results. The conditions under which each assay was conducted were such as to make either a positive or a negative response meaningful. Thus no significance should be read into the relative magnitude of the antidiuretic indices reported. Whatever the magnitude of this index the accompanying " $\mathrm{p}$ " value is alone of importance. A " $p$ " value of 0.03 or less is considered a "positive" assay while a larger value for " $p$ " indicates no significant difference from the control group, and hence, a "negative" assay.

\section{RESULTS}

Table II contains data taken from a representative experiment on subject A. L. Similar representative data on A.R.M. and Dog B are recorded in Tables III and IV, respectively, and Figure 1. Total solute concentration of urine and serum is plotted on the ordinate with time on the abscissa. The rate of urine flow is shown at the bottom. Because two assays could not be done on the same day the dehydration actually is separated by several days from the hydration measurements but for purposes of charting these are combined. The results of several assays done on different occasions also appear in Figure 1.

Following the period of water deprivation there occurred a slight but significant rise of serum total solute concentration above the average normal for each species $(314 \mathrm{mOsm} / \mathrm{L}$ for man and 331 $\mathrm{mOsm} / \mathrm{L}$ for the dog, indicated by the broken line). At this time each was found to be excreting a urine of nearly maximal concentration for its species. Upon administration of water, there resulted a dilution of the serum accompanied by

TABLE II

A. L. Normal male adult

A. Dehydration periods

\begin{tabular}{|c|c|c|c|c|c|c|}
\hline \multirow{2}{*}{ Time } & \multicolumn{2}{|c|}{ Serum } & \multicolumn{2}{|c|}{ Urine } & \multirow{2}{*}{ Prep. } & \multirow{2}{*}{ Assay } \\
\hline & $\begin{array}{l}\text { Solute } \\
\text { conc. }\end{array}$ & $\mathrm{Na}$ & Flow & $\begin{array}{l}\text { Solute } \\
\text { conc. }\end{array}$ & & \\
\hline & $m O s m / L$ & $m E q / L$ & $\mathrm{ml} . / \mathrm{min}$. & $m O s m / L$ & & \\
\hline $4 / 4 / 50$ & 310 & 141 & & 1,020 & $\begin{array}{l}18 \text { hrs. } \\
\text { no water }\end{array}$ & $\begin{array}{c}+38 \\
(p=0.20)\end{array}$ \\
\hline $4 / 25 / 50$ & 315 & 144 & & 923 & $\begin{array}{l}24 \text { hrs. } \\
\text { no water }\end{array}$ & No assay \\
\hline $6 / 21 / 50$ & 316 & 137 & & 1,150 & $\begin{array}{l}24 \text { hrs. } \\
\text { no water }\end{array}$ & No assay \\
\hline
\end{tabular}

B. Hydration period $-7 / 5 / 50$

\begin{tabular}{|c|c|c|c|c|c|}
\hline $\begin{array}{l}\text { Hour } \\
0\end{array}$ & 309 & 144 & & 1,020 & \\
\hline \multicolumn{6}{|c|}{0.5 to $1.670 \mathrm{ml}$. water } \\
\hline $\begin{array}{l}1 \\
2\end{array}$ & 304 & 141 & $\begin{array}{l}1.6 \\
3.3\end{array}$ & $\begin{array}{l}435 \\
126\end{array}$ & $\begin{aligned} &-23 \\
&(p=0.43)\end{aligned}$ \\
\hline 3 & & & 0.8 & 600 & \\
\hline 4 & & & 0.6 & 924 & \\
\hline 5 & & & 0.6 & 900 & \\
\hline 8 & 305 & 144 & 0.5 & 963 & \\
\hline
\end{tabular}

Average normal human serum (water ad lib) $=314 \mathrm{mOsm} / \mathrm{L}$ (range 302-323); $\mathrm{Na}=141 \mathrm{mEq} / \mathrm{L}$ (range 138-144). 
a progressive dilution of the urine until concentrations distinctly hypotonic to the serum or extracellular. fluid were achieved. The rate of urine flow at the bottom of each figure illustrates the water diuresis that occurred. After the administered water load had been excreted the serum and urine total solute concentrations again rose.

Furthermore, at the end of the period of water restriction it was possible to demonstrate antidiuretic activity in the serum obtained from the jugular veins of the dog. During the diuresis that followed water administration, no antidiuretic activity was demonstrated in the serum. In the two normal human subjects antidiuretic activity was not conclusively demonstrated in the serum.

As stated below no claims can be made for the specificity of the antidiuretic assay. That the posterior pituitary is involved in water excretion is common knowledge and that its integrity is essential for the mechanism under discussion is in-

\section{TABLE III}

A. R. M. Normal male adult

A. Dehydration periods

\begin{tabular}{|c|c|c|c|c|c|c|}
\hline \multirow{2}{*}{ Time } & \multicolumn{2}{|c|}{ Serum } & \multicolumn{2}{|c|}{ Urine } & \multirow{2}{*}{ Prep. } & \multirow{2}{*}{ Assay } \\
\hline & $\begin{array}{l}\text { Solute } \\
\text { conc. }\end{array}$ & $\mathrm{Na}$ & Flow & $\begin{array}{l}\text { Solute } \\
\text { conc. }\end{array}$ & & \\
\hline $2 / 9 / 51$ & $\begin{array}{c}m 0 s m / L \\
322\end{array}$ & $\begin{array}{c}m E q / L \\
146\end{array}$ & ml./min. & $\begin{array}{c}m O s m / L \\
1,260\end{array}$ & $\begin{array}{l}24 \text { hrs. } \\
\text { no water }\end{array}$ & $\begin{array}{c}+76 \\
(p=0.09)\end{array}$ \\
\hline $4 / 19 / 51$ & 321 & 143 & & 1,029 & $\begin{array}{l}24 \text { hrs. } \\
\text { no water }\end{array}$ & $\begin{array}{c}-5 \\
(p=0.43)\end{array}$ \\
\hline
\end{tabular}

B. Hydration period-4/16/51

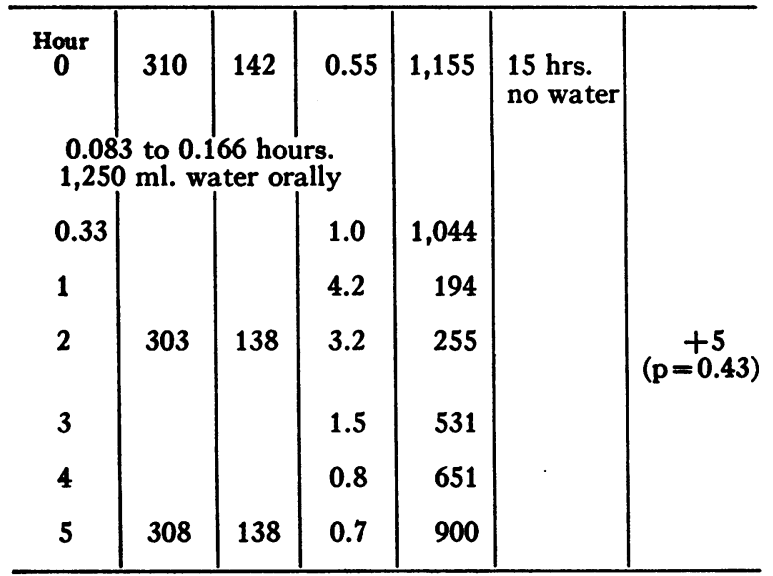

Average normal human serum (water ad lib) $=314 \mathrm{mOsm} / \mathrm{L}$ (range 302-323). $\mathrm{Na}=141 \mathrm{mEq} / \mathrm{L}$ (range $138-144$ ).
TABLE IV

A. Dehydration periods

Dog $B$, Normal

\begin{tabular}{|c|c|c|c|c|c|c|}
\hline \multirow{2}{*}{ Time } & \multicolumn{2}{|c|}{ Serum } & \multicolumn{2}{|c|}{ Urine } & \multirow{2}{*}{ Prep. } & \multirow{2}{*}{ Assay } \\
\hline & $\begin{array}{l}\text { Solute } \\
\text { conc. }\end{array}$ & $\mathrm{Na}$ & Flow & $\begin{array}{l}\text { Solute } \\
\text { conc. }\end{array}$ & & \\
\hline $5 / 9 / 50$ & $\begin{array}{l}m O s m / L \\
331\end{array}$ & $\begin{array}{c}m E q / L \\
154\end{array}$ & ml./min. & $m 0 \mathrm{sm} / L$ & $\begin{array}{l}24 \text { hrs. } \\
\text { no water }\end{array}$ & $\begin{array}{c}+102 \\
(p=0.03)\end{array}$ \\
\hline $10 / 6 / 50$ & 329 & 143 & & 1,860 & $\begin{array}{l}36 \text { hrs. } \\
\text { no water }\end{array}$ & $\begin{array}{c}+118 \\
(p=0.03)\end{array}$ \\
\hline $12 / 6 / 50$ & 360 & 154 & & 2,320 & $\begin{array}{l}48 \text { hrs. } \\
\text { no water }\end{array}$ & $\begin{array}{c}+64 \\
(p=0.20)\end{array}$ \\
\hline $3 / 5 / 51$ & 340 & 150 & & 2,200 & $\begin{array}{l}48 \text { hrs. } \\
\text { no water }\end{array}$ & $\begin{array}{c}+53 \\
(p=0.03)\end{array}$ \\
\hline
\end{tabular}

B. Hydration period-12/4/50

\begin{tabular}{c|c|c|c|c|c|c}
\hline $\begin{array}{l}\text { Hour } \\
0\end{array}$ & 338 & 147 & & 1,800 & & \\
\multicolumn{3}{c|}{$\begin{array}{l}\text { 400 ml. water by } \\
\text { stomach tube }\end{array}$} & & & & \\
1 & & & 0.2 & 655 & & \\
2 & 318 & 144 & 2.2 & 140 & & \\
3 & & & 0.6 & 150 & & \\
4 & 330 & 147 & 0.2 & 655 & & \\
\hline
\end{tabular}

Average normal dog serum (water ad lib) $=331 \mathrm{mOsm} / \mathrm{L}$ (range 320-340);

$\mathrm{Na}=146 \mathrm{mEq} / \mathrm{L}$ (range 145-147).

dicated by the data in Figure 2. The results on two occasions of water deprivation for 14 hours in a patient with posterior pituitary insufficiency are shown. The presence of posterior pituitary insufficiency was established by these data and the patient's ability to elaborate a concentrated urine (1040 mOsm/L) while receiving small amounts of posterior pituitary extract. In Figure 2 it is seen that in spite of severe dehydration as indicated by a very marked increase in serum total solute concentration (the serum sodium concentration rose to $173 \mathrm{mEq} / \mathrm{L}$ in the second period), this patient's urine remained persistently dilute. Similar, though less striking results, have been obtained on three other patients with clinical diabetes insipidus.

\section{DISCUSSION}

According to current physiological concept, which is largely derived from the excellent studies of Verney and his associates, Figure 1 would be 


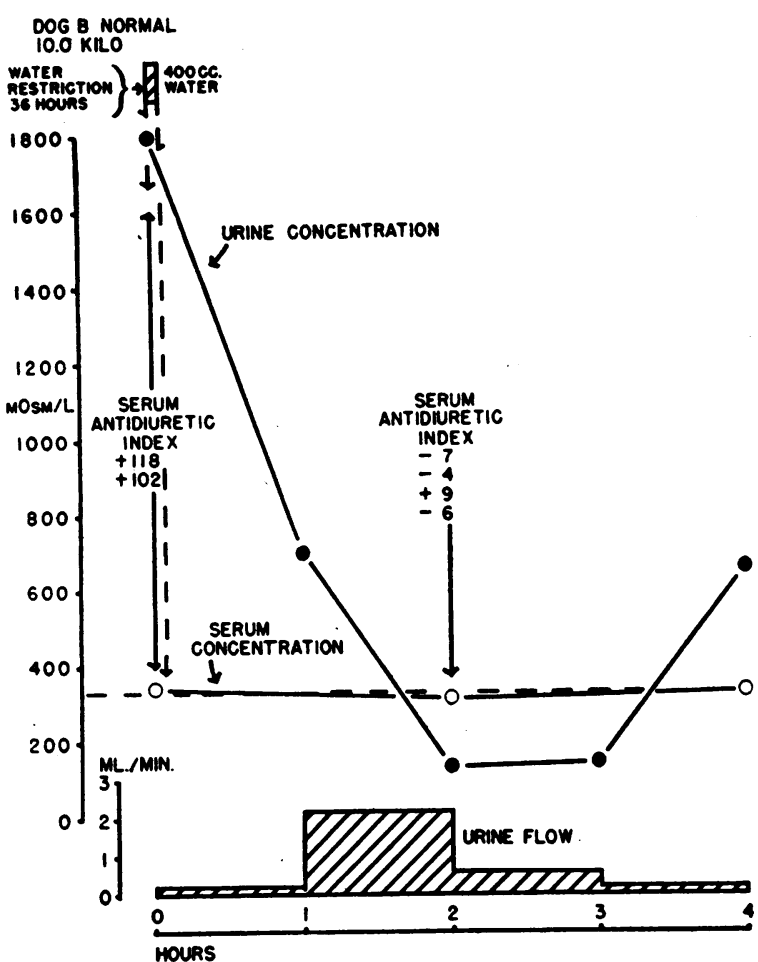

Fig. 1. The Normal Diuretic Pattern in the Dog

Urine and serum total solute concentrations, expressed as milliosmols per liter, are plotted on the ordinate with time on the abscissa. The maximal urine concentration in the dog, about $2,000 \mathrm{mOsm} / \mathrm{L}$, is considerably higher than in man. The average normal total solute concentration of the serum in this species, $331 \mathrm{mOsm} / \mathrm{L}$, is indicated by the broken line. The slight visible changes in serum total solute concentration, from slightly elevated following water restriction to slightly depressed following water administration, serve again to emphasize the effectiveness of this mechanism for preserving a constant serum osmotic pressure in spite of large variations in fluid intake. The serum antidiuretic indices recorded indicate the presence of antidiuretic activity following water restriction when serum solute concentration is increased and urine maximally concentrated, and absence of antidiuretic activity when serum and urine are dilute following water ingestion. This is a composite figure showing data from more than one experiment.

explained as follows: As a result of restricted fluid intake and a continued insensible loss of water from the body there occurs a slight increase in total solute concentration of the serum and extracellular fluid. This stimulates, through "osmoreceptors," an increased activity of the supraopticohypophyseal system with outpouring of antidiuretic hormone. The antidiuretic hormone acts upon the renal tubule cells to produce an increased reabsorption of water from the glomerular filtrate
(12) with resultant formation of a concentrated urine and conservation of body water. The dilution of the extracellular fluid which follows water administration inhibits posterior pituitary activity, creating a state of functional diabetes insipidus which permits diuresis of a dilute urine ridding the body of the excess water load. This cybernetic mechanism is thus seen to be ideally designed to preserve within narrow limits the total solute concentration of the extracellular fluid.

Verney has clearly shown that not all solutes are equally effective in stimulating the osmoreceptors (1). Thus urea was practically noneffective while $\mathrm{NaCl}$ and sucrose in equiosmolar

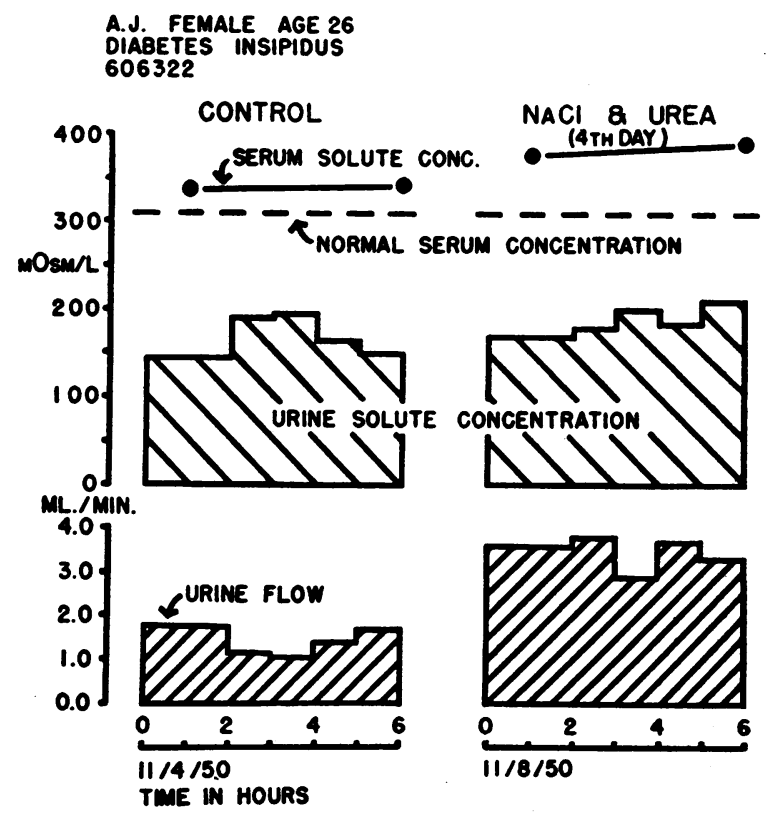

Fig. 2. The Effects on Serum and Urine Total Solute Concentrations of 14 Hours of Water REstriction on Two Occasions in a Patient with DiaBETES INSIPIDUS

On the second occasion sodium chloride $10 \mathrm{gms}$. and urea $15 \mathrm{gms}$. daily had been taken orally on the preceding three days to increase the excretory solute load. Total solute concentrations of serum and urine are plotted on the ordinate. Note that in spite of severe dehydration indicated by the markedly elevated serum total solute concentrations the urine remains very dilute indicating complete loss of ability on the part of the kidneys to conserve body water. However, with injections of small amounts of posterior pituitary extract this patient's kidneys were able to produce a urine of maximal concentration. The inability to concentrate the urine in the presence of dehydration can, therefore, be blamed on a failure of posterior pituitary activity. 
concentrations produced prompt antidiuresis when infused into the internal carotid artery of a dog during a water diuresis. Apparently a substance which distributes itself readily through the intracellular compartment as well as the extracellular fluid fails to set up an osmotic gradient between the cell and its environment and hence fails as a stimulus to the "osmoreceptors." The freezing point determination of total solute concentration, of course, summates all the solutes present in the serum: those which exert an effective osmotic pressure on the osmoreceptors and those that do not. The short period of time over which the changes in serum concentration are observed and the parallel changes in serum sodium concentration obtained indicate that a true dilution is occurring and not just a reduced concentration of a single solute such as urea.

That a measurable dilution in the serum can be found following the enteral administration of as little as $350-400 \mathrm{ml}$. of water to a 10 -kilogram dog or $670 \mathrm{ml}$. of water to a 75-kilogram adult human is somewhat surprising. Assuming total body water to be $60 \%$ of the body weight for both species, $350 \mathrm{ml}$. of water entirely absorbed from the gut and not excreted would result, in the dog, in an expected dilution of the serum of $5.8 \%$ and, in the human studied, $670 \mathrm{ml}$. would correspondingly cause a dilution of $1.5 \%$. That changes of approximately this magnitude were obtained in spite of the presence of diuresis is probably to be explained by the delay in distribution of the ingested water throughout the total body water space. Schloerb and associates (13) found that following oral ingestion of deuterium oxide the rate of absorption from the gut is greater than the rate of distribution throughout the body and that some three hours were required before the serum level fell to the equilibrium concentration following the dose of $\mathrm{D}_{2} \mathrm{O}$ used. Our findings are in accord with those of Baldes and Smirk (14), Margaria (15) and Lifson (16), who measured vapor pressure changes to obtain total solute concentration of serum.

It was hoped that an assay method for antidiuretic activity which measured directly the change in urine concentration would have advantages over the standard methods which depend upon the rate of elimination of a fixed water load. The latter method must depend upon the rate of solute ex- cretion as well as upon the presence or absence of antidiuretic activity (17). Frequently no correlation was observed between urine volume and concentration, presumably due to variations in rate of solute excretion. Also it was hoped that by using post-hypophysectomized animals assay of substances (18-21) which exhibit their antidiuretic effects through release of endogenous antidiuretic hormone would be avoided. However, the posthypophysectomized rats could always on dehydration exhibit the capacity to elaborate a more concentrated urine than the maximum response attained during the assays, so that this possibility is not excluded in the results.

This assay method proved to be very cumbersome, tedious and difficult to control. ${ }^{6}$ Of a total of 72 assays one "false" positive assay (positive response following injections of material known to contain no antidiuretic activity) and many false negative assays were encountered. Though we have a reasonable degree of confidence in the assay results presented we wish to minimize the importance of the assay to our interpretation. No matter how reproducible and sensitive an assay of this type is, it will not prove that antidiuretic material found in the serum is of posterior pituitary origin.

The inability to demonstrate antidiuretic activity in the serum of the human subjects following water deprivation, although we were apparently successful in the dog, is probably attributable to two factors. First, the canine uncomplainingly tolerated longer periods of water deprivation than the humans. Secondly, serum for assay was obtained from the jugular veins of the dog but from the antecubital veins of the humans. The concentration of secretions of the posterior pituitary might be expected to be considerably higher in venous blood from the head than from the arm or leg (8).

The variability that occurs in endogenous posterior pituitary activity from no apparent function during water diuresis to maximal activity during dehydration makes it seem imperative that assays of antidiuretic material in body fluids be carried out under standard conditions of hydration in order to be interpretable. Otherwise, what might be

6 It is expected that an improved form of this assay which can be applied quantitatively will subsequently be reported by Dr. J. D. Crawford. 
concluded to be overactivity of the supraopticohypophyseal system in disease may simply be the normal response of this system to a disturbed state of hydration caused by the disease-i.e., anorexia and nausea causing low fluid intake.

\section{SUMMARY AND CONCLUSIONS}

It is shown that in normal man and dog water deprivation causes a slight rise in serum total solute concentration associated with maximal concentration of the urine. Following water administration there occurs a slight but measurable dilution of the serum. With this the urine becomes progressively more dilute reaching levels distinctly hypotonic to the extracellular fluid. When the administered water load is excreted serum and urine total solute concentrations again rise.

Furthermore, in the dog, the presence of antidiuretic activity in the serum was demonstrated at the end of the period of water deprivation, while no activity was demonstrable during the diuresis that followed water administration. The role of the posterior pituitary in this mechanism is indicated by persistence of dilute urine during dehydration in spite of very marked hypertonicity of the serum in a patient with posterior pituitary insufficiency. Thus it is seen that this cybernetic mechanism is ideally designed to preserve within narrow limits the total effective solute concentration of the serum.

\section{ACKNOWLEDGMENTS}

The authors wish to acknowledge their gratitude to Dr. James Howard Means whose interest and support made possible this study and to thank Dr. J. D. Crawford who generously made available the use of his freezing point depression apparatus. Our thanks also go to Dr. A. M. Butler for his constructive criticism of this manuscript.

\section{REFERENCES}

1. Verney, E. B., Absorption and excretion of water: antidiuretic hormone. Lancet, 1946, 2, 781.

2. Verney, E. B., Antidiuretic hormone and the factors which determine its release. Proc. Roy. Soc. London, Series B, 1947, 135, 25.

3. Gilman, A., and Goodman, L., The secretory response of the posterior pituitary to the need for water conservation. J. Physiol., 1937, 90, 113.

4. Boylston, G. A., and Ivy, A. C., An antidiuretic substance present in the urine of dehydrated rats. Proc. Soc. Exper. Biol. \& Med., 1938, 38, 644.

5. Ingram, W. R., Ladd, L., and Benbow, J. T., The excretion of antidiuretic substance and its relation to the hypothalamico-hypophyseal system in cats. Am. J. Physiol., 1939, 127, 544.
6. Hare, K., Hickey, R. C., and Hare, R., The renal excretion of an antidiuretic substance by the dog. Am. J. Physiol., 1941, 134, 240.

7. Hickey, R. C., and Hare, K., The renal excretion of chloride and water in diabetes insipidus. J. Clin. Invest., 1944, 23, 768.

8. Ames, R. G., Moore, D. H., and van Dyke, H. B., The excretion of posterior pituitary antidiuretic hormone in the urine and its detection in the blood. Endocrinology, 1950, 46, 215.

9. Leaf, A., and Mamby, A. R., An antidiuretic mechanism not regulated by extracellular fluid tonicity. J. Clin. Invest., 1952, 31, 60.

10. Butler, A. M., and Tuthill, E., An application of the uranyl zinc acetate method for determination of sodium in biological material. J. Biol. Chem., 1931, 93, 171.

11. Crawford, J. D., and Nicosia, A. D., A method for determination of freezing points of small quantities of biological fluids. To be published.

12. Smith, H. W., The Kidney. Structure and Function in Health and Disease. Oxford University Press, New York, 1951, p. 257.

13. Schloerb, P. R., Friis-Hansen, B. J., Edelman, I. S., Solomon, A. K., and Moore, F. D., The measurement of total body water in the human subject by deuterium oxide dilution. J. Clin. Invest., 1950, 29, 1296.

14. Baldes, E. J., and Smirk, F. H., The effect of water drinking, mineral starvation and salt administration on the total osmotic pressure of the blood in man, chiefly in relation to the problems of water absorption and water diuresis. J. Physiol., 1934, $82,62$.

15. Margaria, R., The vapour pressure of normal human blood. J. Physiol., 1930, 70, 417.

16. Lifson, N., Note on the total osmotic activity of human plasma or serum. J. Biol. Chem., 1944, 152, 659.

17. Crawford, J. D., Schoen, E. J., and Nicosia, A. D., Factors determining maximum renal water excretion capacity. Proc. Soc. for Ped. Research, May, 1951.

18. de Bodo, R. C., The antidiuretic action of morphine, and its mechanism. J. Pharmacol. \& Exper. Therap., 1944, 82, 74.

19. de Bodo, R. C., and Prescott, K. F., The antidiuretic action of barbiturates (phenobarbital, amytal, pentobarbital) and the mechanism involved in this action. J. Pharmacol. \& Exper. Therap., 1945, 85, 222.

20. Pickford, M., Control of the secretion of antidiuretic hormone from the pars nervosa of the pituitary gland. Physiol. Rev., 1945, 25, 573.

21. Shorr, E., Baez, S., Zweifach, B. W., Payne, M. A., Mazur, A., and Metz, D. B., The antidiuretic action of the hepatic vasodepressor ferritin (VDM) and its occurrence in conditions associated with antidiuresis in man. Tr. A. Am. Physicians, 1950, 63, 39. 